\title{
Mixed Choir and Instruments in the Composition of the Worship Music of the Stations of the Cross
}

\author{
Paulus Dwi Hananto ${ }^{1 凶}$, Pande Made Sukerta ${ }^{2}$ \\ ${ }^{1}$ Universitas Kristen Satya Wacana, Indonesia \\ ${ }^{2}$ Institut Seni Indonesia Surakarta, Indonesia
}

Submitted: June 8, 2020. Revised: September 29, 2020. Accepted: November 4, 2020

\begin{abstract}
The station of the cross is an event of the Passion story of Jesus Christ carrying the cross from the Pilate's palace to the hill of Golgotha. On that journey, Jesus endured torture and humiliation, both from Roman soldiers and Jews. Based on this story, the objective of the research is to describe the process of developing a new compositional composition based on the story of the journey in the format of a choir and a musical ensemble. The research method used in this research is descriptive qualitative. Data collection was carried out through observation, interviews, and documents. After all data has been collected, the next process is to determine the use of scales, instrumentation, and composition based on rhythmic and melodic motifs, time signature, key signature, tempo, and composition of song texts. The choice of musical signs is adjusted to the meaning of the lyrics used. The composition of the Song of the Station of the Cross which is composed is a combination of a mixed choir consisting of soprano, alto, tenor, and bass with a musical ensemble. The novelty of the composition of the Song of the Station the Cross lies in the use of the style of baroque passions (1600-1750), aria, and recitative combined with modern harmonies, namely the use of the seventh tone, the ninth tone, and the thirteenth tone of a chord, and the use of Indonesian as the whole text of the composition
\end{abstract}

Keywords: composition; song of the station of the cross; ensemble; worship music

How to Cite: Hananto, P. D., \& Sukerta, P. M. (2020). Mixed Choir and Instruments in the Composition of the Worship Music of the Stations of the Cross. Harmonia: Journal of Arts Research And Education, 20(2), 231-241

\section{INTRODUCTION}

The Station of the Cross is a religion offering (devotion) to the Passion story of the journey of Jesus Christ. As the Savior, Jesus was willing to humble himself as the most despicable human being, by carrying the cross, which was the most despicable symbol at that time. Jesus carried the cross as an illustration that He took all the sins of mankind. Jesus turned the cross as a symbol of humiliation into a symbol of victory and glory with His resurrection from the dead. The tradition of 'the station of the cross' for Catholics is set in a deep devotion to the narrative of the suffering (via dolorosa) of Jesus. This kind of devotion is usually carried out during the Lenten period, but is gaining popularity today due to the Catholics' fondness for the activities of pilgrimage-recreation.

The journey of the Station of the Cross began when Jesus was sentenced to death by the Jewish priests in front of Pontius Pilate and ended up on a rock called Golgotha which means skull (Indonesi-

\footnotetext{
Corresponding author:

E-mail: paulus.hananto@uksw.edu
} 
an Bible Society, 1974). The Station of the Cross event is not merely a description of the suffering story of Jesus Christ but reflects the noble values of the meaning of sacrifice which are now beginning to be abandoned. In that incident, Jesus immediately gave an example of a sacrifice that was selfless and wanted to love and pray for those who persecuted Him. Therefore, through this incident, Jesus reminded his people about the meaning of loving others, serving others, and making peace with God to lead to salvation.

Several composers have produced musical compositions with the background of the station of the cross, including Johann Sebastian Bach with Gospel of John (the St John Passion), the Gospel of Matthew (the St Matthew Passion), Christus (Op.97, 1847) by Felix Mendelssohn, Les sept paroles du Christ by Cesar Franck, John Stainer's The Crucifixion (1887), Die Passion (Op. 93, 1896) by Heinrich von Herzogenberg, and Christus. Mysterium is a Prelude and Three Oratorios (Opp. 70-73, 1899) by Felix Draeseke. Meanwhile, in the 20th century, composers who composed similar compositions, including St. Luke Passion (1965) by Krzysztof Penderecki, Passio (1982) by the composer Estonian Arvo Pärt, and Passionsmusik nach dem Lukasevangelium by Rudolf Mauersberger (Ammer, 2004).

The compositions were all composed using the format of choir and orchestra in Latin, English, and German. Based on the analysis of several compositions, such as (1) Saint Mathew Passion (a Passion of Jesus according to Saint Matthew) composed by Johann Sebastian Bach; and (2) St. Luke Passion (1965) composed by Polish Krzysztof Penderecki; and (3) the Passion (1982) composed by Estonian Arvo Pärt, there are major differences, especially in terms of the use of harmonization and composition writing techniques (Kennedy, 2003).

Song of the Station of the Cross is not just a form of translation of events raised in a musical work but has a connection with contextual aspects. Ruswanto (2017) has argued Christians believe that culture is a form of God in Christ "incarnation" who turned Himself to be human and showed God's kindness to the world. The presence of Christ in the world is represented by culture, i.e., Hebrew. However, His presence in the world has inspired the inculturation of local culture and liturgy.

Based on the analysis of these musical works, a musical composition that combines vocal and instrumental works is compiled in this study. As a new work that is different from previous works, the process of creating and arranging music in this study is still based on phenomena or events that reflect the story of the station of the cross. In addition, this research needs to be carried out because the author did not find similar compositions composed in Indonesian, so that the resulting composition will enrich the existing musical repertoire.

\section{METHOD}

The research was carried out with descriptive and experimental analysis by relying on qualitative data. Thus, the form is more of an explanation, description, and real picture of the subject under study. As for substantively, the research was carried out using a musicological approach that was supported by music theory, harmony science, arrangement, form science, and music analysis. The research data comes from research subjects such as resource persons, students, and composers who have knowledge and insights that support the research objectives.

The data collection techniques used in this study were observation, interview, and documentation. Documentation techniques are used to obtain secondary data to complement the data obtained through observation and interview techniques. The technique of checking the validity of the data was carried out in two ways, namely triangulation of data and review of sources. Data analysis was performed by using interactive model analysis which consisted of three stages, namely 
data reduction, data presentation, and conclusion (verification) (Miles \& Huberman, 1992).

\section{RESULTS AND DISCUSSION}

\section{Procession and Composition of Music Part I (Court Session)}

The procession at the Court Session begins with the setting of all the presenters outside the performance building. During the dark night during the procession, the lights inside and outside the performance building were put out. So that the lighting only uses candle lights along the right and left stairs leading into the performance building. In Christian customs, Jesus as the light of the world is symbolized by a candle flame (Indonesian Bible Society, 1974). When everything is ready, the Master of Ceremony reads a short narrative about the events of the Station of the Cross of Jesus Christ which is followed by a piano sound in medium tempo with gentle dynamics. The piano sounds are played in the following pattern,

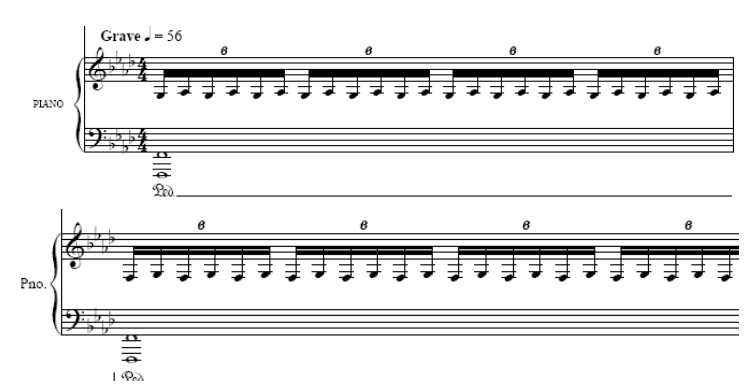

Figure 1. The intro motif of bar $1-2$ is played in the piano music instrument at fermata 1.

The pattern of the motif is repeated until all the music presenters enter the performance building.

After that, the procession is continued to enter the building with its head bowed, which slowly divided into two directions. The head is bowed as a reflection of the contemplation of the Station of the Cross, while the slow (grave) and heavy walking implies the weight of the cross that everyone walks (Randell, 1999; Jarret, 2008). The front part of the procession is the presenter carrying the cross, followed by the choir group, then the presenters playing the instruments. After all the presenters arrived at the stage, the choir group continued to sing the song 'Crucify $\mathrm{Him}^{\prime}$ in a mixed choir formation for about 5 minutes.

After the chorus is finished, there is a chime in medium tempo followed by didgeridoo's incoming sound in long notes for about 15 seconds, followed by a piano sound with long notes in the lower register. The lower register's use is to build a dark and heavy atmosphere, as a reflection of the beginning of the Station of the Cross (Bell, 2012).

After the piano sound, the Bass chorus continues by singing the melody pattern as follows.

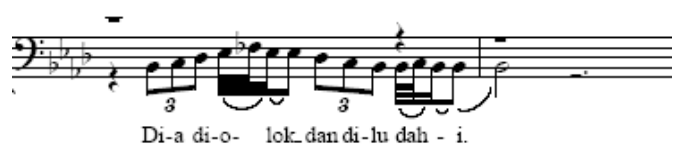

Figure 2. The melody pattern 1 at fermata 2 (bar 5).

Then followed by the voice of tenor and bass singers who sing the following melody patterns.

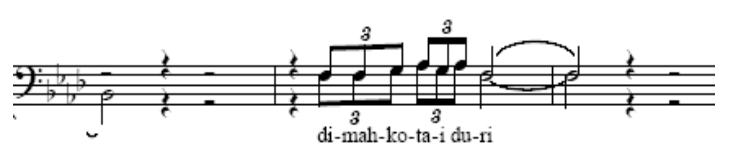

Figure 3. The melody pattern 2 at fermata 2 (bar 8-10)

On bar 13-14, the tenor and bass singers sing the following melody pattern.

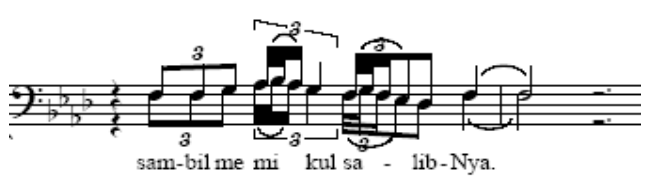

Figure 4. The melody pattern 3 at fermata 2 (bar 13-14)

After that, the alto singers sing the melody pattern 1 which is sung by Bass, while the tenor and Bass singers sing the new melody pattern in a longer duration as a contrast to the melody on bar 19-20, 
26, and 27-28.

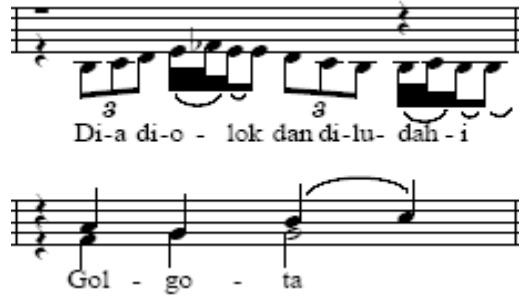

Figure 5. The melody pattern 4 at fermata 2 (bar 19-20)

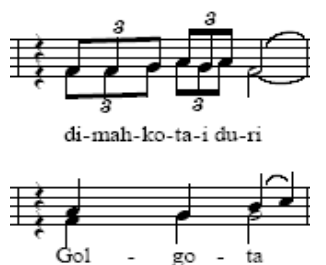

Figure 6. The melody pattern 5 at fermata 2 (bar 26)

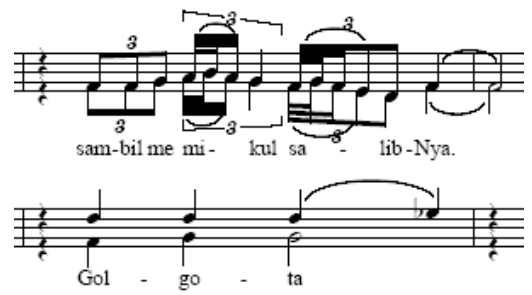

Figure 7. The melody pattern 6 at fermata 2 (bar 27-28)

Soprano, Alto, Tenor, and Bass sing the new pattern unisono at a faster tempo. This section also repeats the rhythmic pattern to give a heavy and dramatic impression which is analogous to Jesus' journey to Golgotha by carrying the cross (Pankhurst, 2008).

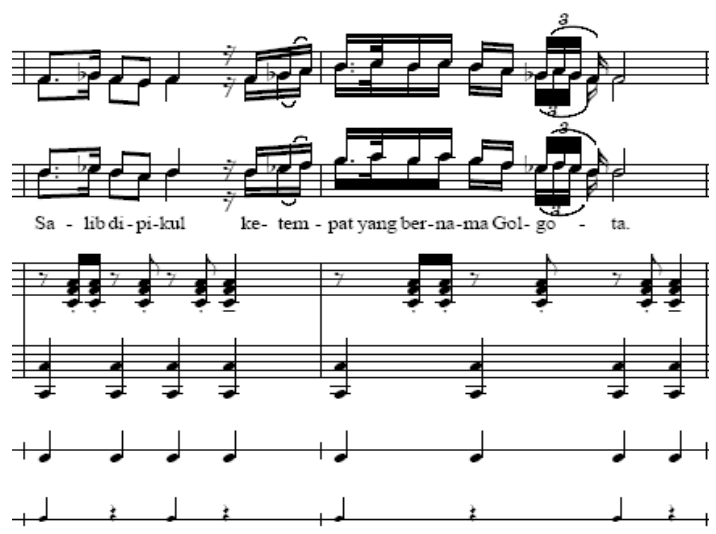

Figure 8. Fermata 2 at bar 41-42
The next part of the music is followed by piano and cymbal sound that play repetitive sound patterns to create an atmosphere of tension. The sound patterns of piano and cymbal in this section are as follows.

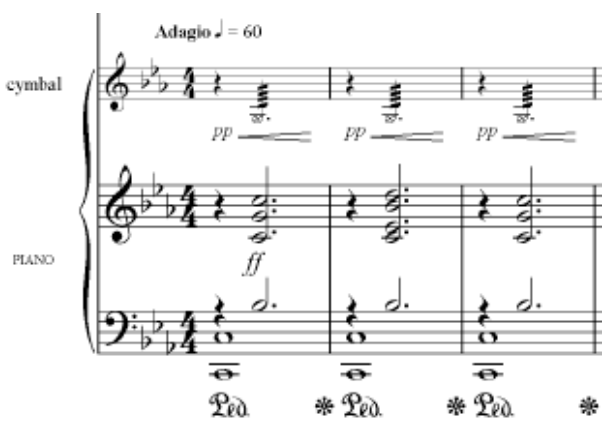

Figure 9. Pattern 1 at fermata 3 bar 1-3

In this section, the piano is played with loud dynamics, while the cymbal is played from soft to hard step by step. After playing the pattern, the piano and cymbal play the second pattern music with dynamics from hard to soft, and the tempo is getting slower. The second pattern notation in that section is as follows.

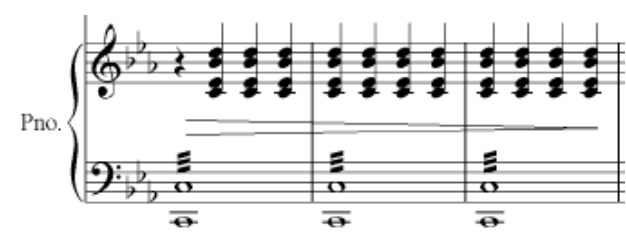

Figure 10. Pattern 2 at fermata 3 bar 9-11

After a moment of silence, pattern 1 is played back together with the chorus in very loud dynamics (fff) with the lyrics "Jesus Christ". The repetition of pattern 1 in this section is as follows.

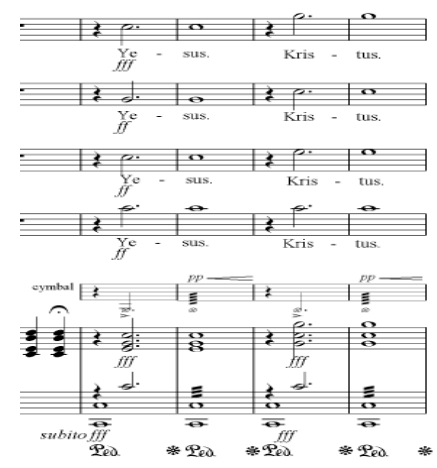

Figure 11. Pattern 1 at fermata 3 bars 13-16 
After that part, the choir group sang the new melody as follows.

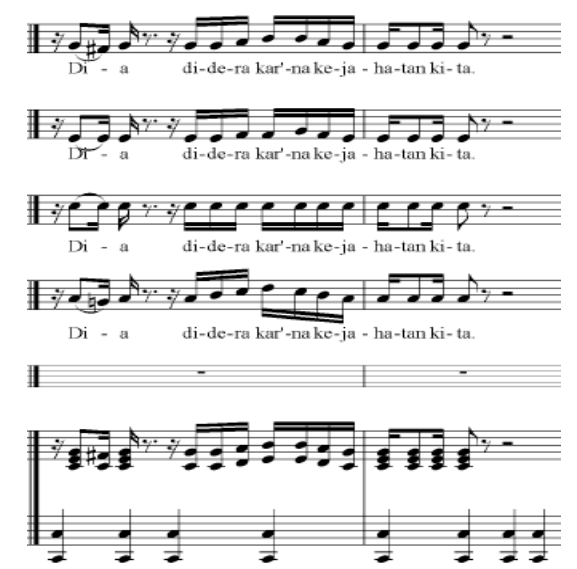

Figure 12. Pattern 3 at fermata 3 bar 20-21

Pattern 3 is sung repeatedly with different lyrics. Lyric 1 is "Dia didera karena kejahatan kita". Lyric 2 is "Dia didera karena dosa-dosa kita". The lyrics 1 and 2 are sung for two times and are continued again in the song pattern 1 with a different harmony. After that, it is followed by the presence of a new pattern, namely pattern 4 with the following notation.

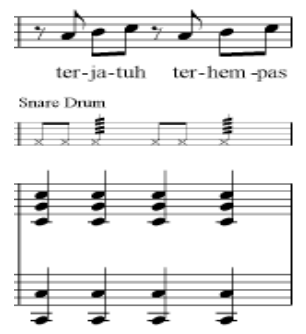

Figure 13. Pattern 4 at fermata 3 bar 37

In this section, the bass singers sing the lyric "Terjatuh, terhempas, karena dosa $k i t a "$ twice. In the following section, the bass and tenor singers sing the lyric " $\mathrm{Di}$ cambuk, ditikam, untuk selamat kita" in the same pattern twice. Then, the bass, tenor, and alto singers sing the lyrics "Bilur-Nya, darah-Nya, silih dosa kita" in the same pattern twice. This section ends by singing pattern 1. Part I ends with the choir leaving the stage.

\section{Procession and Composition of Music Part II (Faithfulness)}

At the time the choir left the stage, a solo female vocal continues to sing accompanied by a piano. While singing, the singer walks slowly towards the stage. This style of singing is called responsorial (Unger, 2010). The female vocal soloist in the procession and music composition in this section is analogous to Mary, the mother of Jesus, who courageously and faithfully accompanies Jesus' journey in carrying His cross.

After this part, the instrument of flute plays the melody with a slow tempo. The dynamics are not too loud and expressive. The flow of the melody is as follows.

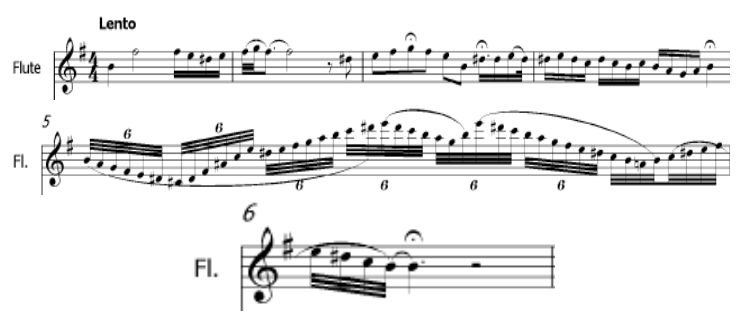

Figure 14. The flute melody pattern at fermata 6 (bar 1-6)

The melody pattern above is repeated with the following variations.

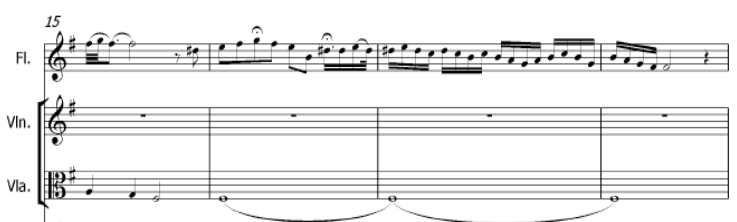

Figure 15. The flute melody pattern at fermata 6 bar 15-18

After this part, the viola is played in long notes. Then the flute returns to playing the main melody, followed by the sound of the viola playing a long note as a counter-melody (Schachter, 2012). Then proceed with the entry of the guitar sound with block chord and flute in a fixed melody pattern. The music notation in this section is as follows. 


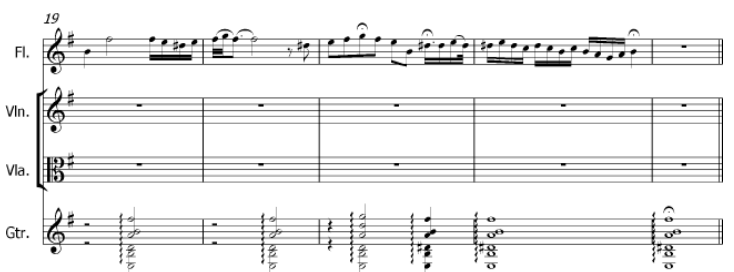

Figure 16. Fermata 6 at bar 19-23

The next part enters the sound of the violin and viola with a repetitive rhythm pattern. This atmosphere is maintained for approximately one minute, and then the guitar sound is continued with the arpeggio technique followed by the instrument of flute by playing the following melody pattern.

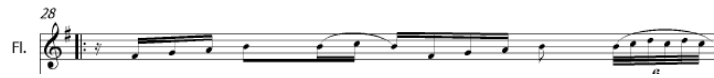

Figure 17. Fermata 6 at bar 28

The pattern is repeated with the register one octave higher. Whereas in the next section, the musical instrument of guitar plays the main melody played by the flute with several variations as follows.

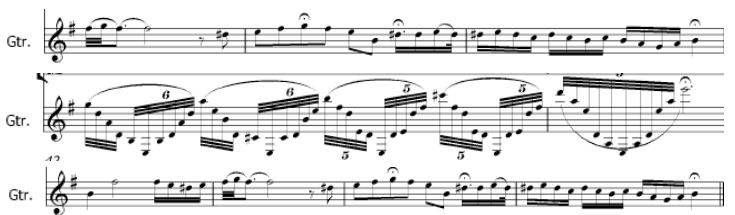

Figure 18. Fermata 6 at bar 37-45

\section{Procession and Composition of Music Part III (Obedience)}

This section begins by describing the time when Jesus fell the second time. In this section, the musical composition is a choir singing the melody and lyrics of the song "Dia didera karena kejahatan kita". The complete melody and song lyrics are as follows.
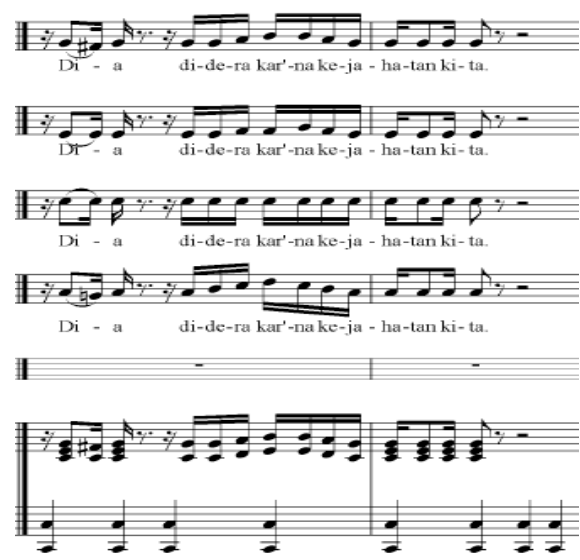

Figure 19. Fermata 3 at bar 19-20

This part of the story is not carried on until it is finished but is followed by another section which tells of the women of Jerusalem when weeping over Jesus' suffering on his way to carry the cross to Golgotha. This part is presented in a kind of choir, namely the soprano and alto, as well as a male vocal solo. In this section, the female vocals only sound the vowels a, $i$, e. The presentation begins with the soprano 1 with vocal $a$, which flows in a slow tempo, followed by the soprano 2 with vocal $a$ with a similar melody pattern.

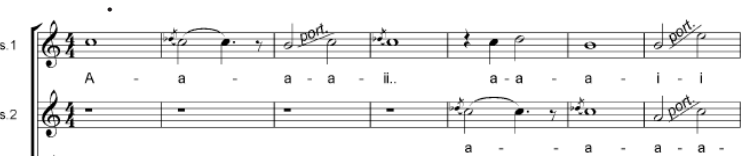

Figure 20. The melody of Soprano 1 and Soprano 2 at fermata 8 bar 1-7

After that part, the alto sings almost the same melody pattern as the development of the melody pattern of soprano 1 . The melody pattern is as follows.

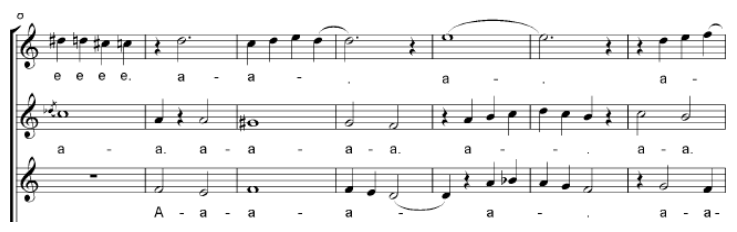

Figure 21. Fermata 8 at bar 8-14 
Followed by the voices of the soprano 1 , soprano 2 , and alto singing the same rhythm pattern with a different melody. The rhythm pattern and the flow of the melody are as follows.

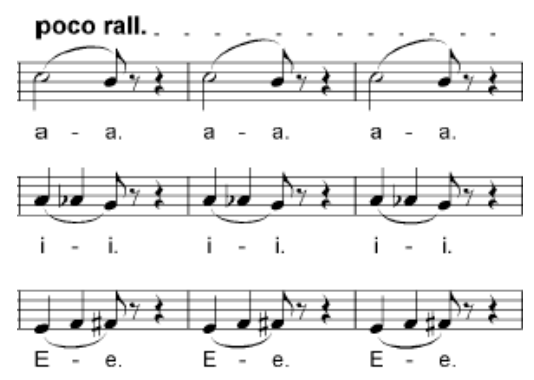

Figure 22. Fermata 8 at bar 19-21

This section is repeated with progressively gentler dynamics. Then proceed with the entry of the male vocal solo with free rhythms as follows.

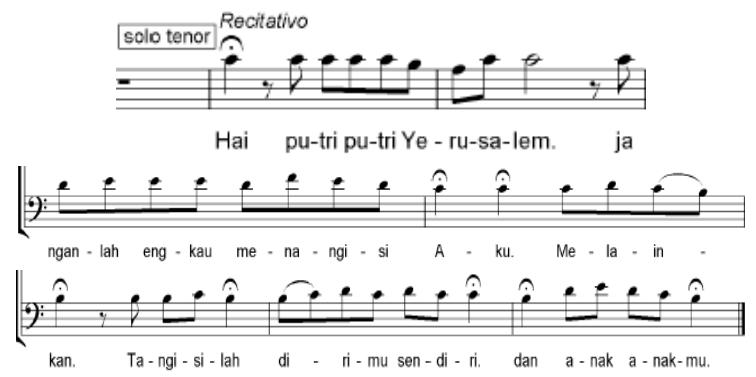

Figure 23. Fermata 8 at bar 26-32

In the next part of the procession, it tells about Jesus when he fell the third time. In this section, the music composition is presented in the form of a choir. Besides, followed by the entry of the sound of a didgeridoo, the piano is in a low register to present a dark impression (Absil, 2015, p. 19). It is followed by the bass vocal voice singing the lyrics "janganlah kita potong, mari kita undi. Siapa mendapatkannya". The melody and lyrics of the song in this section are as follows.

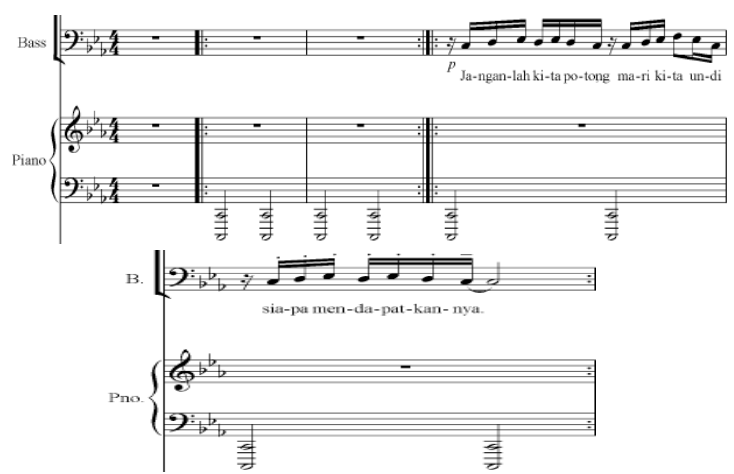

Figure 24. Fermata 10 at bar 1-5

Then the choir sings the lyric "genaplah apa yang tertuliskan. Pakaian-Mu dibagibagikan" with the following arrangement.

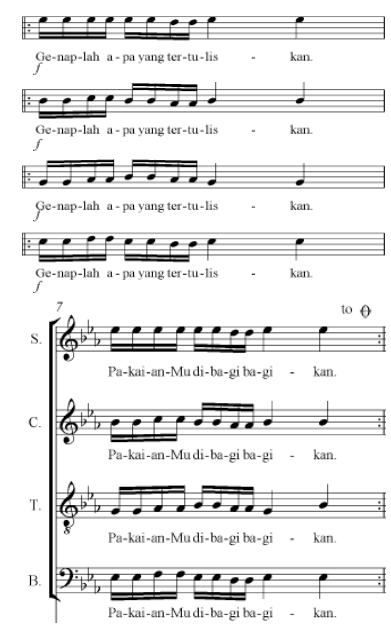

Figure 25. Fermata 10 at 6-7

After the section, the bass with the vocal a, followed by the tenor, alto, and soprano, sings the melody with the vocal a. This pattern is performed in the following polyphony and Gregorian style.

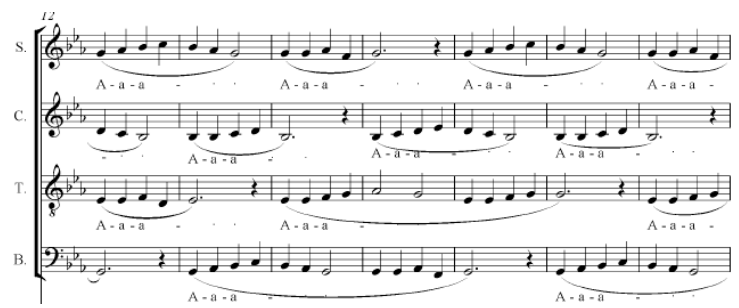

Figure 26. Fermata 10 at bar 12-18 
After repeating the beginning, the male vocal solo sings the song with the lyric "ketika Aku telanjang, kamu memberi Aku pakaian" in the following free rhythm.

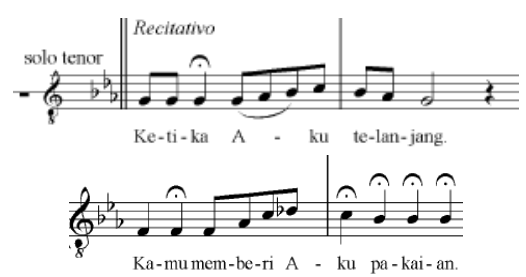

Figure 27. Fermata 10 at bar 22-24

Then the choir follows with a faster tempo in a homophonic style. The lyric of the song in this section is "pakaian-Mu ditanggalkan, pakaian-Mu dibagikan". The tone sang and the lyric of the songs in this section are as follows.

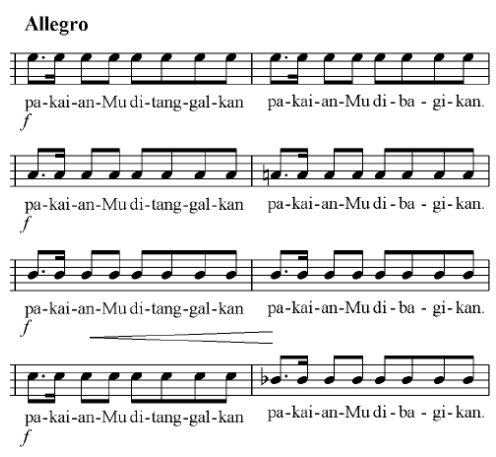

Figure 28. Fermata 10 at bar 8-9

Then, the male vocal solo sings the song with the lyric "Ketika Aku sakit, kamu melawat Aku" at fermata 10 bar 29-32 as follow.

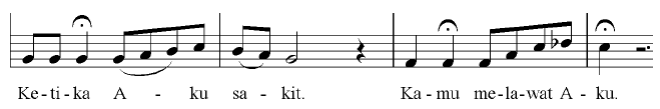

Figure 29. Fermata 10 at bar 29-32

Then, the choir sings at a faster tempo in a homophonic style. The lyric of the song in this section is "martabat-Mu direndahkan. Martabat-Mudihinakan."

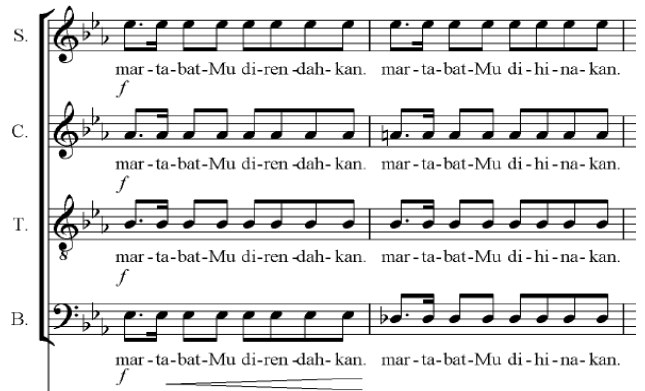

Figure 30. Fermata 10 at bar 33-34

Then, the male vocal solo sings the song with the lyric "Ketika Aku dalam penjara, kamu mengujungi Aku". The notation of melody and lyric in this section is as follows.

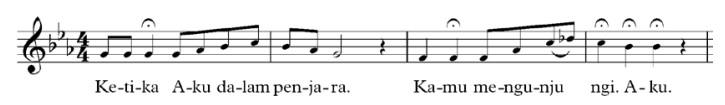

Figure 31. Fermata 10 at bar 36-39

After that, the choir sings at a faster tempo in a homophonic style with the lyric "Kau tinggikan harkatku. Kau tinggikan harkatku". The notation of melody and lyric in this section is as follows.

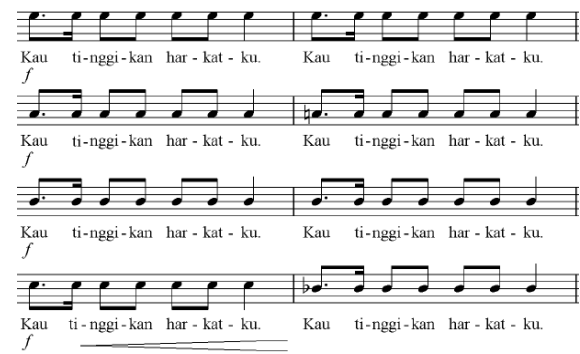

Figure 32. Fermata 10 at bar 40-41

\section{Procession and Composition of Music Part IV (Surrender)}

This section is the final part of the story of Jesus' journey in carrying the cross. In this section, the music composition is marked by the end of the song from the choir. After a brief pause, the solo saxophone sound plays the melodic patterns of a varied flute ensemble. 


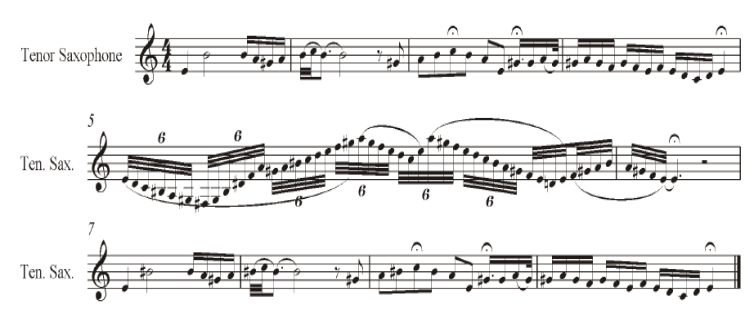

Figure 33. The melody of Solo Saxophone at bar 1-10

The melodic patterns that are played are repeated with variations in the rhythm, duration, register, and tempo patterns. As the saxophone plays the melody, the choir group walks in a circle on the stage slowly while lowering their heads.

In the art of music, as in life, moving towards the goal encounters obstacles, reversals, disappointments, and involves great distances, decors, expansion, interpolation, and, in short, retardations of all kinds. Therein lies the source of all artistic delaying, from which the creative mind can derive content that is never new. Thus, we hear in the middle-ground and foreground an almost dramatic course of events (Pankhurst, 2008).

Creating new songs can be done by developing and cultivating existing musical motives (Juanita, 2005). Therefore, the novelty of the composition of the Station of the Cross in this study lies in the use of the Baroque passion style (1600-1750), the aria singing style, which is an elaboration of the solo singing style with accompaniment and recitative, a singing style like a talking person combined with modern harmony, namely the use of the seventh note, the ninth note, and the thirteenth note of a chord (Ammer, 2004). In addition, it is also aimed at using Indonesian as the overall text of the composition.

The novelty of the composition of the Song of the Station of the Cross in this study was expressed by validators such as Agastya who stated that the composition of the Song of the Station of the Cross was a new composition inspired by the procession of the station of the cross in the tradition of the Catholic church. The compositions are variously created according to the phenomena and events of the story of the Station of the Cross, which consists of 14 (fourteen) fermatas, namely: (1) Jesus is sentenced to death; (2) Jesus carries the cross; (3) Jesus falls for the first time; (4) Jesus meets his mother; Simon of Kirine helps (5) Jesus; (6) Veronika rubs the face of Jesus; (7) Jesus falls for the second time; (8) Jesus comforts the women who wept for Him; (9) Jesus falls for the third time; (10) Jesus' clothes were taken off; (11) Jesus is crucified; (12) Jesus dies on the cross; (13) Jesus is taken down from the cross; and (14) Jesus is buried.

The exclamations, dialogues, narratives in the procession of the station of the cross are adopted and summarized in the composition of the Song of the Station of the Cross into four parts without repetition (Stein, 1974). Therefore, this composition is one of the most spectacular new works of the modern era. The existing harmonization and melody reflect novelty, complex aspects of rhythm, interval, harmonization, and bridge. This was revealed by Adimurti, one of the three validators involved in this study.

Agastya also mentioned that from the language aspect, the composition of St John Passion and Johann Sebastian Bach's St. Luke Passion is written in German text, while Passio et mors Domini nostri Iesu Christi by Krzysztof Penderecky and Passion Domini Jesu Christi by Arvo Pärt used Latin text. Meanwhile, the text used in the writing of the Song of the Station of the Cross is in Indonesian. As for the source aspect, Johann Sebastian Bach wrote the story of the Passion of Jesus based on the Gospels of Matthew and Luke; Krzysztof Penderecki is based on the Gospel of Luke, and Arvo Pärt is based on the Gospel of John. Meanwhile, the Song of the Station of the Cross by Paulus Dwi Hananto uses text quoted from the Gospel of Matthew.

In the aspect of composition, JS Bach, Krzysztof Penderecki, and Arvo Pärt use the following compositions of singers: (1) evangelist, (2) Jesus Christ, (3) Pontius Pilate, (4) Peter, and (5) choir; meanwhile, Pau- 
lus Dwi Hananto uses the following singer lineup: (1) male solo, (2) female solo, and (3) choir. JS Bach uses string instruments, flute, oboe, and basso continuo; Krzysztof Penderecki uses a complete orchestra formation; and Arvo Pärt uses the violin, cello, oboe, bassoon, and organ. On the other hand, Paulus Dwi Hananto uses less common instrumentation, namely: violin 1 and 2, viola, violoncello, flute, saxophone, didgeridoo, guitar, and percussion instruments consisting of: drum, snare drum, floor tom-tom, cymbal, triangle, tambourine, and bells (Listya, interviewed on 27 September 2020).

\section{CONCLUSION}

The Song of the Station of the Cross is a composition composed based on the story of the Passion of Jesus. This composition was composed using choral and ensemble formats. The choral composition is the main repertoire that wraps the composition from start to finish using Indonesian language song lyrics. The use of flute wind instruments with a soft character and violin and violin instruments with lyrical characters in this composition is expected to build an atmosphere in each part of the composition. Meanwhile, the use of didgeridoo, which has a deep voice and low register, is expected to create an atmosphere of suffering that Jesus experienced during His journey of carrying the cross.

The procession and music composition part 1 to part 4 is a complete composition. Structurally this composition is in the form of $\mathrm{A}, \mathrm{B}, \mathrm{C}, \mathrm{D}$ because there is no repetition. Types of percussion instruments used are drum, snare drum, floor tom-tom, cymbal, triangle, tambourine, and bell. The use of the drum is likened to the stubbornness of the heart and the steadiness of Jesus Christ's feet in treading the path of His cross. In contrast, the bell is presented to support the sacred atmosphere that we want to build from the beginning to the end of this composition. Compared with existing similar compositions, this composition's novelty, namely the composition of a mixed choir consisting of violin 1 and 2, viola, violoncello, combined with the flute, saxophone, didgeridoo, guitar, as well as a choir with songs with lyrics in Indonesian.

\section{REFERENCES}

Absil, F. (2015). Musical Analysis: Visiting the Great Composers (5th Edition). Retrieved from (https:/ / www.fransabsil.nl/archpdf/musanbk.pdf).

Adimurti, J. T. (2005). Inkulturasi Musik Gereja Di Batak Toba Dan Simalungun. Harmonia: Journal of Arts Research and Education, 6(3), 1-9.

Ammer, C. (2004). Dictionary of Music, Fourth Edition. New York: The Facts on File, Inc.

Bell, D. S. \&. Dylan. (2012). A Capella Arranging. NJ: Hal Leonard Books.

Jarret, S. \& Holly D. (2008). Music Composition for Dummies. Indianapolis. Wiley Publishing, Inc.

Kennedy, M. (2003). The Concise Oxford Dictionary of Music. Great Clarendon Street, Oxford: Oxford University Press.

Komisi, K. W. I. (2002). Puji Syukur: Buku Doa dan Nyanyian Gerejawi. Jakarta: Penerbit Obor.

Lembaga Alkitab Indonesia. (1974). Alkitab. Bogor: Percetakan Lembaga Alkitab Indonesia.

Miles, M. B. \&. Huberman, A. M. (1992). Analisis Data Kualitatif Buku Sumber Tentang Metode-Metode Baru. Edited by T. R. Rohidi. Jakarta: UI-Press.

Pankhurst, T. (2008). A Brief Handbook and Website for Schenkerian Analysis. New York: Routledge.

Randel, D. M. (1999). The Harvard Concisedictionary of Music and Musicians. The Belknap Press of Harvard University Press.

Ruswanto, Y. (2017). Church Music Inculturation by Way of an Experiment of Arrangement of Dolo-Dolo Mass Ordinarium Accompaniment- Composed by Mateus Weruin for Woodwind Quinte. Harmonia: Journal of 
Arts Research and Education, 17(1), Tim Penyusun Kamus Pusat Bahasa. 23-30.

Schachter, C. (2012). The Art of Tonal Analysis. New York: Oxford University Press.

Stein, L. (1979). Structure \& Style: The Study Analysis of Musical Forms. New Jersey: Summy Birchard Music. (2008). Kamus Bahasa Indonesia. Jakarta: Pusat Bahasa Departemen Pendidikan Nasional.

Unger, M. P. (2010). Historical Dictionary of Choral Music. USA: The Scarecrow Press, Inc. 